\title{
KAJIAN YURIDIS TERHADAP PENERAPAN PASAL 21 AYAT 1 KITAB UNDANG UNDANG HUKUM ACARA PIDANA (KUHAP) TENTANG PENAHANAN ATAU PENAHANAN LANJUTAN
}

\author{
Karyoto, Oktabilla Ayu Lestari \\ 1. Universitas Islam Kadiri, Kediri \\ 2. Pengadilan Negeri Nganjuk \\ Email: ayu oktabilla767@gmail.com
}

\begin{abstract}
The tendency for protection of suspects or defendants in the Criminal Procedure Code is understandable. This is because suspects or defendants are particularly vulnerable to violations of their human rights, especially in the context of law enforcement. The suspect or defendant is in the position of the examination object in the process. All series of processes, whether in the examination phase of witnesses, expert examinations, evidence collection, and other evidence collection, are directed to a suspect or defendant, either to convict or not to be guilty

The aims of this study are: (1) To know the meaning of the obscurity of the norm in the sentence "in the case of a concerning circumstance" contained in Article 21 paragraph (1) of the Criminal Procedure Code on detention or continued detention. (2). To know and to learn the racial / basic establishment in the provisions of Article 21 paragraph (1) of the Criminal Procedure Code which contains "anxiety condition" in the case of further detention or detention.

This research method uses conceptual approach, statute approach and historical approach.

The results of the study are: Arrangement of continued detention and detention in the Criminal Procedure Code is highly subjective and tends to have a very wide and unlimited interpretation. This is a blatant disregard for the legal norms governing the detention and continued detention. Detention refers to the provisions of Article 21 of the Criminal Procedure Code requiring a further detention or detention order be made against a suspect or defendant allegedly committing a crime on the basis of sufficient evidence and escape concerns, removing evidence or reprising his crime. In the provisions of that article is contained subjective opportunities for resistance to a person. Worry obviously depends on the subjective feeling of the investigator, prosecutor or judge. The absence of the parameters in the phrase "circumstances of concern" that are not explicitly regulated, both within the Criminal Procedure Code itself and in its implementing rules, are particularly vulnerable to buman rights violations, especially to suspects or defendants beld without filled first in circumstances that cause concern in advance.
\end{abstract}

Keywords: Criminal Procedure Code (Kuhap), Detention, Follow-up Detention, Human Rights

\section{A. PENDAHULUAN}

Kitab Undang-Undang Hukum Acara Pidana (KUHAP) sebenarnya tidak memberikan definisi tentang hukum acara pidana tetapi bagian-bagiannya seperti penyidikan, penuntutan, mengadili, praperadilan, putusan, upaya hukum, penyitaan, penggeledahan, penangkapan, penahanan, dan lain-lain.

Pemerintah merumuskan hukum pidana (materi) sebagai keseluruhan peraturan hukum yang menunjukkan perbuatan mana yang seharusnya dikenakan pidana dan dimana pidana itu seharusnya menjelma. Hukum Acara Pidana biasa disebut juga sebagai hukum pidana formal yaitu: hukum yang mengatur bagaimana Negara melalui alat-alatnya melaksanakan haknya untuk memidana dan menjatuhkan pidana ${ }^{1}$.

Dalam melaksanakan tugas penegakan hukum, aparat hukum, baik Kepolisian, Kejaksaan, maupun Hakim di Pengadilan diberikan wewenang untuk melakukan upaya paksa (dwang middelen)/ Sanksi terhadap orang yang diduga melakukan tindak pidana. Upaya paksa/ Sanksi tersebut diberikan dalam rangka memperlancar pelaksanaan tugas penegakan hukum.

Penahanan dan penahanan lanjutan merupakan salah satu upaya paksa yang dimiliki oleh pejabat berwenang dalam setiap tingkatan, baik Penyidik di tingkat Kepolisian, Penuntut Umum di Kejaksaan, dan Hakim di Pengadilan. Penahanan menurut ketentuan Pasal 1 angka 21 Kitab Undang-undang Hukum Acara Pidana "Penahanan adalah penempatan tersangka atau terdakwa di

\footnotetext{
${ }_{1}^{1}$ Andi Hamzah, Hukum Acara Pidana Indonesia. Edisi Revisi. Cetakan Ketiga.Jakarta: Sinar Grafika,2004, hal. 4
} 
tempat tertentu oleh penyidik, atau penuntut umum atau hakim dengan penetapannya, dalam hal serta menurut cara yang diatur dalam undang-undang ini".

Dalam Pasal 21 ayat (1) Kitab Undang-undang Hukum Acara Pidana disebutkan:

Perintah penahanan atau penahanan lanjutan dilakukan terhadap seorang tersangka atau terdakwa yang diduga keras melakukan tindak pidana berdasarkan bukti yang cukup, dalam hal adanya keadaan yang menimbulkan kekhawatiran bahwa tersangka atau terdakwa akan melarikan diri, merusak atau menghilangkan barang bukti dan atau mengulangi tindak pidana.

Pengertian penahanan menurut W.J.S Poerwodarminta seperti yang dikutip Joko Prakoso ialah perbuatan menahan yaitu mengurung atau memenjarakan orang ${ }^{2}$. Dari dua pengertian tersebut, pada hakekatnya penahanan merupakan perbuatan penyidik, atau penuntut umum, atau hakim untuk menahan tersangka atau terdakwa dalam tempat tertentu yaitu rumah tahanan Negara, rumah tinggal kediaman tersangka atau kota tempat tinggal kediaman tersangka atau terdakwa.

Kecenderungan perlindungan terhadap tersangka atau terdakwa dalam Kitab Undangundang Hukum Acara Pidana memang dapat dipahami.Hal ini karena tersangka atau terdakwa sangat rentan terlanggar hak asasi manusianya, khususnya dalam konteks penegakan hukum. Tersangka atau terdakwa berada dalam posisi obyek pemeriksaan dalam proses tersebut. Semua rangkaian proses, baik dalam tahap pemeriksaan saksi-saksi, pemeriksaan ahli, pengumpulan barang bukti, dan pengumpulan alat bukti lainnya, diarahkan kepada tersangka atau terdakwa, baik untuk menyatakan bersalah atau tidak bersalah

Penahanan pada dasarnya adalah perampasan terhadap sebagian hak asasi manusia seseorang. Ketentuan Pasal 27 ayat (1) Undang-undang Nomor 39 tahun 1999 tentang hak asasi manusia, menyebutkan "Setiap warga negara Indonesia berhak untuk secara bebas bergerak berpindah dan bertempat tinggal dalam wilayah negara Republik Indonesia". Selain itu ketentuan Pasal 34 Undang-undang Nomor 39 tahun 1999 tersebut disebutkan, "Setiap orang tidak boleh ditangkap, ditahan, disiksa, dikucilkan, diasingkan, atau dibuang secara sewenang-wenang".

Kalimat "dalam hal adanya keadaan yang menimbulkan kekhawatiran..." seharusnya ditafsirkan secara tegas dan jelas. Hal tersebut berbeda dengan ketentuan Pasal 21 ayat (1) Kitab Undang-undang Hukum Acara Pidana yang tidak memberikan batasan atau pengertian yang tegas dan jelas mengenai "keadaan yang menimbulkan kekhawatiran". Penjelasan atas ketentuan Pasal 21 ayat (1) Kitab Undang-undang Hukum Acara Pidana tersebut, hanya dinyatakan dengan kalimat"cukup jelas". Demikian pula di dalam Peraturan Pemerintah Nomor 27 tahun 1983 tentang Pelaksanaan Kitab Undang-undang Hukum Acara Pidana, yang tidak menyebutkan secara limitatif penafsiran "keadaan yang menimbulkan kekhawatiran" tersebut. Sehingga dalam penerapannya cenderung ditafsirkan subyektif oleh aparat penegak hukum dalam melakukan penahanan terhadap tersangka atau terdakwa.

Ketidakjelasan pengertian "keadaan yang menimbulkan kekhawatiran", menunjukan adanya kekaburan norma (vague norm), dan akibatnya memunculkan adanya potensi kesewenang-wenangan, yang merupakan pelanggaran atas hak asasi manusia terhadap tersangka atau terdakwa. Penafsiran yang sangat subyektif dari ketentuan tersebut dapat menjadi ajang "perdagangan kewenangan" dalam prakteknya oleh oknum aparat penegak hukum yang koruptif.

\section{METODE}

Penelitian hukum dapat dilakukan dengan menggunakan penelitian yang khas ilmu hukum yang disebut penelitian hukum normatif ${ }^{3}$, yaitu penelitian yang difokuskan untuk mengkaji penerapan kaidah-kaidah atau norma-norma dalam hukum positif. ${ }^{4}$

Penelitian ini sesuai dengan rumusan masalah sebagai obyek penelitian yang akan dibahas, maka yang akan digunakan adalah pendekatan konseptual (conceptual approach), pendekatan peraturan perundang-undangan (statute approach) dan pendekatan sejarah (bistorical approach). Pendekatan

2 Djoko Prakoso, Kedudukan Justiciable didalam KUHAP, Ghalia Indonesia, Jakarta, 1986. hal 121

${ }^{3}$ Universitas Jambi, Program Magister Ilmu Hukum, Pedoman Tesis Magister Ilmu Hukum, Jambi, 2008, hal. 12

4Johnny Ibrahim, Teori Metodologi Penelitian Hukum Normatif, Bayumedia Publishing, Surabaya, 2006, hal. 295 
konsep (conceptual approach) dilakukan dengan meneliti asas-asas hukum dan teori-teori yang relevan dengan alasan-alasan penahanan dan penahanan lanjutan terhadap tersangka atau terdakwa. Pendekatan peraturan perundang-undangan (statute approach), yaitu pendekatan yang dilakukan melalui analisis norma dari berbagai peraturan perundang-undangan yang berhubungan dengan penahanan dan penahanan lanjutan terhadap tersangka atau terdakwa, baik berbentuk hukum positif maupun masih berbentuk rancangan. Sedangkan pendekatan sejarah (bistorical approach) dilakukan dengan meneliti sejarah pembentukan Kitab Undang-undang Hukum Acara Pidana dan kaitannya dengan pasal 21 ayat (1) pada waktu pembentukannya dahulu.

Pengumpulan bahan hukum primer dan sekunder dengan menggunakan sistem kartu (card system). Hal ini dilakukan untuk mempermudah proses penganalisisan. Bahan-bahan hukum tersebut diperoleh melalui berbagai sumber hukum. Dari berbagai sumber hukum tersebut kemudian digunakan sebagai sumber penulisan dan penelitian ini, diperoleh jenis-jenis bahan hukum, yaitu:

a) Bahan hukum primer terdiri dari peraturan perundang-undangan yang dibahas seperti: Kitab Undang-undang Hukum Acara Pidana, Undang-undang Nomor 39 Tahun 1999 tentang Hak Asasi Manusia, dan peraturan perundang-undangan lainnya yang berkaitan dengan pengaturan penahanan dan penahanan lanjutan terhadap tersangka atau terdakwa.

b) Bahan hukum sekunder, yaitu bahan hukum yang dapat memberikan penjelasan mengenai bahan hukum primer, seperti: rancangan undang-undang, jurnal hukum, makalah, hasil-hasil penelitian, hasil karya dari kalangan hukum yang dapat berupa buku, majalah, artikel, artikel ilmiah, dan lain-lain.

c) Bahan hukum tertier, yaitu bahan hukum yang dapat memberikan petunjuk maupun penjelasan terhadap bahan hukum primer dan sekunder, seperti: kamus, ensiklopedia, dan lainnya.

Setelah bahan-bahan hukum tersebut terkumpul, maka dilakukan analisis terhadap pengertian-pengertian hukum dan norma-norma hukum. Dengan cara melihat isi dari berbagai macam peraturan perundang-undangan yang berhubungan dengan Kajian Yuridis terhadap Penerapan Pasal 21 ayat (1) KUHAP tentang Penahan atau Penahan Lanjutan. Penganalisasisan terhadap isi bahan hukum dengan melakukan interpretasi, menilai dan melakukan evaluasi.

\section{PEMBAHASAN}

\section{Penahanan Menurut Rancangan Kitab Undang-undang Hukum Acara Pidana}

Undang - undang No. 8 Tahun 1981 tentang Kitab Undang - Undang Hukum Acara Pidana (KUHAP) telah berusia lebih dari seperempat abad. KUHAP sering disebut sebagai hasil karya "agung" bangsa Indonesia yang merupakan hasil karya pemikiran para pakar hukum acara pidana Indonesia yang disertai dengan integritas dan semangat untuk mewujudkan penyelenggaraan pemerintahan yang melindungi kepentingan warga negaranya sesuai dengan pembukaan UUD 1945.

Rancangan Kitab Undang-undang Hukum Acara Pidana tetap memberikan wewenang penahanan kepada penyidik, penuntut umum, dan hakim. Penahanan juga harus dilakukan dengan surat perintah penahanan atau penetapan hakim. Kemudian di dalam surat perintah atau penatapan penahanan tersebut juga harus memuat alasan penahanan, uraian singkat perkara tindak pidana yang disangkakan atau didakwakan, serta harus mencantumkan tempat tersangka atau terdakwa ditahan.

Namun dalam Rancangan Kitab Undang-undang Hukum Acara Pidana mengenal adanya hakim komisaris. Berdasarkan Pasal 58 jo. Pasal 60 Rancangan Kitab Undang-undang Hukum Acara Pidana, penyidik dan penuntut umum yang melakukan penyidikan berwenang melakukan penahanan. Untuk kepentingan pemeriksaan pada tahap penyidikan, hakim komisaris atas permintaan penyidik melalui penuntut umum berwenang memberikan persetujuan perpanjangan penahanan terhadap tersangka.

Dalam waktu 1 (satu) hari terhitung sejak penahanan, tembusan surat perintah penahanan atau penetapan hakim harus diberikan kepada keluarga atau wali tersangka atau terdakwa, lurah, atau kepala desa atau nama lainnya tempat tersangka atau terdakwa ditangkap, orang yang ditunjuk oleh tersangka atau terdakwa, dan/atau komandan kesatuan tersangka atau terdakwa, dalam hal tersangka atau terdakwa yang ditahan adalah anggota Tentara Nasional Indonesia karena melakukan tindak pidana umum.

Tindak pidana yang dapat dikenakan penahanan masih sama dengan Pasal 21 ayat (4) Kitab Undang-undang Hukum Acara Pidana (Pasal 59 Rancangan Kitab Undang-undang Hukum Acara 
Pidana), tetapi alasan untuk menahan diperluas. Penahanan dapat dilakukan terhadap tersangka atau terdakwa yang diduga keras melakukan tindak pidana berdasarkan bukti awal yang cukup dan adanya kekhawatiran bahwa tersangka atau terdakwa akan:

a. Melarikan diri

b. Merusak dan menghilangkan alat bukti dan/atau barang bukti

c. Mempengaruhi saksi

d. Melakukan ulang tindak pidana, dan/atau

e. Untuk kepentingan keselamatan tersangka atau terdakwa dengan persetujuannya (Pasal 59 ayat (5) Rancangan Kitab Undang-undang Hukum Acara Pidana)

Rancangan Kitab Undang-undang Hukum Acara Pidana tidak mengenal lembaga praperadilan, oleh karena kewenangan penahanan telah dialihkan menjadi kewenangan hakim komisaris.Apabila pelaksanaan penahanan telah menjadi kewenangan hakim komisaris, keberadaan lembaga praperadilan memang menjadi tidak relevan.

Dari uraian tersebut diatas, terlihat bahwa dalam Rancangan Kitab Undang-undang Hukum Acara Pidana masih mempertahankan penafsiran subyektif keadaan yang menimbulkan kekhawatiran untuk dilakukannya penahanan, tanpa memberikan batasan yang tegas dan jelas mengenai keadaan-keadaan apa saja yang dapat menimbulkan kekhawatiran tersebut. Perbedaannya terletak pada lamanya penahanan yang dapat dikenakan terhadap tersangka atau terdakwa yang lebih singkat dibandingkan dengan Kitab Undang-undang Hukum Acara Pidana. Hal ini tentu merupakan kemajuan yang positif, oleh karena akan memacu para penegak hukum menyelesaikan tugas penegakan hukum, tanpa mengorbankan hak asasi manusia tersangka atau terdakwa yang dikenakan penahanan.

\section{Landasan Filosofis}

Undang-undang Nomor 8 tahun 1981 tentang Kitab Undang-undang Hukum Acara Pidana merupakan pelopor hukum formil nasional di Indonesia.Dalam konsideransnya, pemerintah dan DPR sebagai pembentuk Undang-undang menyatakan pembentukan Kitab Undang-undang Hukum Acara Pidana adalah usaha untuk peningkatan dan penyempurnaan pembinaan hukum nasional dengan mengadakan pembaharuan kodifikasi serta unifikasi hukum dalam rangkuman pelaksanaan secara nyata dari wawasan nusantara. Dengan memberikan penegasan bahwa Indonesia adalah negara hukum yang berdasarkan Pancasila dan Undang-undang Dasar 1945, maka secara filosofis muatan Kitab Undang-undang Hukum Acara Pidana tidak boleh bertentangan dan selalu berorientasi pada Pancasila dan Undang-undang Dasar 1945 tersebut.

Pembentukan Kitab Undang-undang Hukum Acara Pidana juga dimaksudkan untuk menggantikan peran Het Her:iene Inlandsch Reglement (Stb. 1941-44) dihubungkan dengan Undangundang Nomor 1/Drt/1951 (LN. 1959-9) beserta semua peraturan pelaksanaannya, sebagai hukum acara pidana yang berlaku. Diakui memang apabila dibandingkan dengan Het Herziene Inlandsch Reglement, khususnya dalam hal penahanan Kitab Undang-undang Hukum Acara Pidana lebih baik dan lebih menghargai hak asasi manusia seseorang. Sebagaimana yang telah diuraikan dalam bab sebelumnya, dalam Het Herziene Inlandsch Reglement seorang tersangka atau terdakwa dapat ditahan, tanpa batas waktu yang jelas. Sedangkan dalam Kitab Undang-undang Hukum Acara Pidana penahanan, baik oleh penyidik, penuntut umum maupun oleh hakim di pengadilan mempunyai batas waktu yang jelas.

Politik kolonial cenderung mengutamakan kepentingan penguasa daripada hak-hak asasi manusia warga yang dijajahnya. Secara umum hal tersebut adalah logis, oleh karena setiap penguasa, khususnya penjajah akan berusaha semaksimal mungkin mempertahankan kekuasaannya, salah satunya dengan merekayasa instrumen hukum di negara tersebut. Di dalam Sidang Dewan Perwakilan Rakyat pada tanggal 9 Oktober 1979, pemerintah menjelaskan bahwa:

1. Het Herziene Inlandsch Reglement adalah produk legislatif penjajah, sehingga tidak sesuai lagi dengan keadaan dan perkembangan dewasa ini;

2. Kurang memperhatikan hak-hak pencari keadilan dan lebih memperhatikan kepentingan penguasa;

3. Tidak mengatur hak-hak tersangka/tertuduh, serta hak-hak lain yang penting bagi kelancaran pemeriksaan perkara; 
4. Tidak berdasar pada alinea ke-4 Pembukaan Undang-undang Dasar 1945, yang menyebutkan: "Negara berdasar atas Ketuhanan Yang Maha Esa menurut dasar Kemanusiaan Yang Adil dan Beradab"s.

Walaupun dianggap sebagai karya agung (masterpiece) dan menjadikan Pancasila dan Undangundang Dasar 1945 sebagai landasan filosofisnya, namun sebagai produk manusia Kitab Undangundang Hukum Acara Pidana juga terlepas dari beberapa kekurangan dalam melindungi hak asasi manusia. Kritik sebagian kalangan menyatakan Kitab Undang-undang Hukum Acara Pidana lebih melindungi tersangka atau terdakwa. Sebagai perangkat hukum yang mengatur mengenai tata cara penegakan hukum pidana materiil, Kitab Undang-undang Hukum Acara Pidana memang didesain lebih banyak melindungi hak asasi manusia tersangka atau terdakwa. Dalam konteks ini sebenarnya yang perlu dipahami adalah muatan Kitab Undang-undang Hukum Acara Pidana memang ditujukan dalam rangka penegakan hukum.

Dengan demikian jelas bahwa landasan filosofis Kitab Undang-undang Hukum Acara Pidana adalah Pancasila dan Undang-undang Dasar 1945.Landasan ini tentunya juga harus menjiwai seluruh peraturan perundang-undangan yang menjadi turunan atau pelaksanaan dari Kitab Undangundang Hukum Acara Pidana sendiri.Baik peraturan pemerintah atau peraturan perundangundangan lainnya, yang menjadikan Kitab Undang-undang Hukum Acara Pidana sebagai acuan.Tidak hanya itu, penegak hukumnya sebagai pelaksana dari Kitab Undang-undang Hukum Acara Pidana juga seharusnya mengamalkan nilai-nilai dalam Pancasila dan Undang-undang Dasar 1945.Selalu mengingat dan tidak terlepas dari nilai Ketuhanan, juga harus bertindak tidak sewenangwenang antar sesama manusia, dan lain-lain.

\section{Landasan Sosiologis}

Selain landasan filosofis, penting pula mengkaji landasan sosiologis pembentukan Kitab Undang-undang Hukum Acara Pidana.Dimana ada masyarakat disitu ada hukum (ubi societas ibi ius).Pembentukan hukum tentunya tidak lepas dari kondisi atau keadaan masyarakat di daerah tersebut.Hukum tercipta karena telah ada masyarakat terlebih dahulu yang tinggal, menetap dan berhubungan atau bersosialisasi di wilayah itu.Dengan demikian maka aturan-aturan yang terbentuk bersumber dari keinginan-keinginan dan kesepakatan-kesepakatan masyarakat.

Kitab Undang-undang Hukum Acara Pidana disahkan oleh Presiden Soeharto pada tanggal 31 Desember 1981 melalui Undang-undang Nomor 8 tahun 1981; Lembaran Negara Republik Indonesia No. 76; Tambahan Lembaran Negara No. $3209^{6}$. Pembentukan Kitab Undang-undang Hukum Acara Pidana yang dilakukan pada awal era 1980-an, tentunya tidak terlepas dari kondisi dan keadaan keamanan dan politik hukum penguasa pada waktu itu.

Secara sosiologis kondisi keamanan pada sekitar tahun 1980-an memang diwarnai oleh maraknya kejahatan-kejahatan jalanan. Pencurian dengan kekerasan yang disertai perkosaan, pembunuhan, kemudian yang dilakukan di angkutan umum, telah meresahkan penguasa negeri ini.

Kondisi sosiologis keamanan yang cukup mengkhawatirkan ternyata mendorong penguasa untuk mengambil tindakan instant dalam melakukan penegakan hukum dan pencegahan kejahatan. Masyarakat yang pada awalnya takut akan kejahatan-kejahatan jalanan, kemudian hanya beralih menjadi takut akan penculikan-penculikan dan pembunuhan yang terjadi. Meskipun masyarakat yang takut pada awalnya adalah masyarakat umum berubah menjadi kelompok masyarakat yang takut adalah para penjahat-penjahat jalanan dan keluarganya.

Dari uraian tersebut jelas bahwa Kitab Undang-undang Hukum Acara Pidana sebagai hukum acara pidana dibuat dalam masa kejahatan-kejahatan jalanan merajalela.Kondisi keamanan tersebut kemudian mendorong penguasa mengambil langkah-langkah instant, walaupun langkah tersebut melanggar hak asasi manusia.Kondisi psikologis penguasa ini, ikut berpengaruh pada Kitab

${ }^{5}$ Sukinta, Beberapa Perbedaan Penting Antara KITAB UNDANG-UNDANG HUKUM ACARA PIDANA dan Het Herziene Inlandsch Reglement, Makalah pada Fakultas Hukum Universitas Diponegoro, Semarang, 1997, hal. 9-10

${ }^{6}$ Yahya Harahap. 2009. Pembahasan Permasalahan dan Penerapan Kitab Undang-undang Hukum Acara Pidana.Penyidikan dan Penuntutan. Edisi Kedua. Cet. Ke-12. Sinar Grafika. Jakarta.Martiman Prodjohamidjojo. 1982. Penangkapan dan Penahanan. Ghalia Indonesia, Jakarta, hal. 23 
Undang-undang Hukum Acara Pidana yang terbentuk dan masih berlaku sampai dengan sekarang.Upaya paksa yang salah satunya adalah penahanan dalam Kitab Undang-undang Hukum Acara Pidana, diberikan dengan kewenangan yang sangat bersifat subyektif.Keadaan ini adalah untuk memudahkan para penegak hukum dalam melakukan tugas dan kewenangannya secara maksimal.Dengan harapan kejahatan-kejahatan jalanan dapat diminimalisir dengan sekecil-kecilnya.

\section{Landasan Yuridis}

UUD 1945 terutama Pasal 20 (tentag legislasi), Pasal 21 (Hak DPR mengajukan Rancangan udang - undang), Pasal 22 (HakPresiden untuk mengajukan PERPU), Pasal 22A (tata cara pembentukan undang - undang), Pasal 24 (kekuasaan kehakiman), Pasal 24A (wewenang Mahkamah Agung), Pasal 24C (wewenang Mahkamah Konstitusi), Pasal 28A sampai dengan Pasal 28J (Hak Asasi Manusia).

Pasal 27 UUD 1945 berbunyi "Segala warga negara bersamaan kedudukannya di dalam hukum dan pemerintahan dan wajib menjungjung hukum dan pemerintahan itu dengan tidak ada kecualiannya". Dengan demikian pemerintah harus membuat ketentuan yang mengatur bahwa kedudukan hukum setiap warga negara sama/ sederajat. KUHAP merupakan salah satu ketentuan peraturan perundang - undangan yang mengatur mengenai hal tersebut

\section{KESIMPULAN}

Kesimpulan dalam jurnal ini adalah:

1. Pengaturan penahanan dan penahanan lanjutan dalam Kitab Undang-undang Hukum Acara Pidana sangat bersifat subyektif dan cenderung mempunyai penafsiran yang sangat luas dan tidak terbatas. Hal ini merupakan kekaburan terhadap norma hukum yang mengatur mengenai penahanan dan penahanan lanjutan tersebut. Ketiadaan paramater dalam kalimat "keadaan yang dapat menimbulkan kekhawatiran" yang tidak diatur secara tegas, baik di dalam Kitab Undangundang Hukum Acara Pidana sendiri maupun dalam aturan pelaksananya, sangat rentan menimbulkan pelanggaran hak asasi manusia

2. Penahanan mengacu kepada ketentuan pasal 21 KUHAP yang mensyaratkan perintah penahanan atau penahanan lanjutan dilakukan terhadap seorang tersangka atau terdakwa yang diduga keras melakukan tindak pidana berdasarkan bukti yang cukup dan kekhawatiran melarikan diri, menghilangkan barag bukti atau mengulang tindak pidananya. Dalam ketentuan pasal tersebut terkandung peluang - peluang subjektif untuk melakukan panahanan terhadap seseorang. Rasa khawatir jelas tergantung perasaaan subjektif penyidik, jaksa maupun hakim tanpa dipenuhi terlebih dahulu adanya keadaan yang menimbulkan kekhawatiran terlebih dahulu.

\section{E. DAFTAR PUSTAKA}

Andi Hamzah, 2011. Hukum Acara Pidana Indonesia. Penerbit Sinar Grafika : Jakarta.

Djoko Prakoso, 1986, Kedudukan Justiciable didalam KUHAP, Ghalia Indonesia, Jakarta,

Inge Amundsen. 2000. Corruption: Definitions and Concepts. Chr. Michelsen Institute Development Studiest and Human Rights.

Johnny Ibrahim. 2006. Teori Metodologi Penelitian Hukum Normatif. Bayumedia Publishing, Surabaya.

M. Yahya Harahap. 2009. Pembahasan Permasalaban dan Penerapan Kitab Undang-undang Hukum Acara

Pidana.Penyidikan dan Penuntutan. Edisi Kedua. Cet. Ke-12. Sinar Grafika. Jakarta.Martiman Prodjohamidjojo. 1982. Penangkapan dan Penahanan. Ghalia Indonesia, Jakarta

Sukinta, 1997, Beberapa Perbedaan Penting Antara KITAB UND ANG-UND ANG HUKUM ACARA PID ANA dan Het Herriene Inlandsch Reglement, Makalah pada Fakultas Hukum Universitas Diponegoro, Semarang.

Universitas Jambi. 2008. Program Magister Ilmu Hukum. Pedoman Tesis Magister Imu Hukum, Jambi. Republik Indonesia, Undang-undang Nomor 8 Tahun 1981 tentang Kitab Undang-undang Hukum Acara Pidana (Lembaran Negara Republik Indonesia Tahun 1981 Nomor 76, Tambahan Lembaran Negara Republik Indonesia Nomor 3209). 